\title{
Study on the Application of Financial Sharing Simulation Training Platform on Practice Teaching
}

\author{
Haiqing $\mathrm{Xu}^{1}$, Jing $\mathrm{Cao}^{1}$, Sijin $\mathrm{Li}^{1}$ \\ ${ }^{1}$ Dianchi College of Yunnan University, Kunming, Yunnan, 650000
}

Keywords: financial sharing simulation training platform; accounting professional; practical teaching

\begin{abstract}
With the globalization of the economy and the rapid development of Internet technology, financial sharing services have become a brand-new management model that has been adopted by more and more large-scale group companies, and the demand structure of companies for talent has also undergone tremendous changes. As a practice-oriented undergraduate college with a strong practicality in finance and accounting, it is necessary to embed the financial sharing service model in teaching, which not only promotes the comprehensive development of students, but also meets the needs of enterprises and society. This paper analyzes the current status of practical teaching development in applied universities and the impact and impact of financial sharing services on practical teaching. Based on existing practical teaching, it constructs and designs a financial sharing simulation training platform and enhances the practice teaching model, in order to meet the financial sharing trend and the demand for financial personnel.
\end{abstract}

\section{Introduction}

This management model of financial sharing originated from the American Ford Company in the 1980s. This management model is mainly based on information technology, emphasizing the business process of the company. Its main role is to gather accounting services in different locations into a shared service. The central office collects and records the accounts. This kind of benefits ensures the standardization and consistency of accounting records and reports, and at the same time greatly reduces labor costs.

The purpose of financial sharing is to effectively integrate the internally distributed, highly reproducible financial services into an independent information platform to achieve unified processing, thereby better integrating resources and reducing costs, and creating more value for enterprises. At the same time, it can well solve the drawbacks of repeated investment and inefficiency in the construction of financial functions.

According to the statistics of the British Institute of Certified Public Accountants, more than 80\% of the Fortune 500 companies have established financial sharing service centers. In China, there are also many large-scale group companies that have gradually achieved financial sharing, such as ZTE, Haier, Ping an, and Huawei, and have achieved standardized, streamlined, and standardized financial processing. Therefore, establishing a financial sharing service center and realizing financial sharing services has become an inevitable trend for future business development.

\section{The Effect of Financial Sharing Service Center on Accounting Practice Teaching in Applied Undergraduate Colleges}

At present, most of the personnel training programs for accounting majors of applied-type undergraduate colleges emphasize the importance of practice. On the basis of theoretical teaching, the intensity of practical teaching is greatly enhanced. However, under the trend of rapid development of the financial sharing service center, comprehensively, there are still some problems in practical teaching of various application-oriented universities.

The related courses of practical teaching are more traditional and single, lack of integrity, and cannot meet the needs of enterprise development. 
The main courses offered by most practical undergraduate colleges and universities in practice teaching are: "Embedded" teaching in the freshman and sophomore years, integrating practical teaching courses into theoretical courses, such as the use of accounting principles and practical training courses. The cashier practice module" and the primary accounting practice course use the "Kingdee K3 basic platform" for teaching; the junior and senior year courses offer practical teaching selective courses to enhance students' practical hands-on capabilities, such as: entrepreneurial management and industrial sandbox, accounting Computerization and ERP experiments, business and enterprise countermeasures for sand tables, etc.; to the senior year, a course of "cross-specialized integrated simulation and training” was set up, and students' comprehensive utilization capabilities were enhanced by simulating the company's production and operation activities.

From the point of view of practical teaching courses, it is more unified and complete than before, and it is distributed in the four grades of universities. Formally speaking, these courses are also more diverse. However, these courses are relatively independent and the links between courses are not close enough. Lack of integrity. More importantly, although these courses can allow students to understand the entire process of business operations, allow students to master the business process of accounting and computerization, and be able to formulate correct corporate decisions based on a changing business environment. However, this kind of training mode is relatively traditional, and there is still a big gap with practice. Especially for the rapidly developing financial sharing service center, such a way is that it is impossible for students to get in line with practice and quickly integrate into the practice of the enterprise.

The implementation of financial sharing has become an inevitable trend for future business development. Under the financial sharing model, the financial accounting function becomes the foundation, and more importantly, the accounting information system can timely and accurately provide useful information for the company's various decision-making analysis, and realize the comprehensive development of the industry finance integration. It can also be said that the simple financial accounting work has not been able to meet the needs of economic and social development at this stage. The financial work of the enterprise is changing from "accounting finance" to "management finance" and then to "strategic finance".

Under the financial sharing service model, the basic financial accounting work will be centralized and unified, and the positioning of financial personnel will also shift from financial accounting to management accounting. The transformation of financial roles, working methods and content will require higher and higher financial personnel's overall quality. Therefore, the traditional accounting professional education focuses on the education of professional skills, and more emphasis on the mastery of financial accounting, ignoring the quality of financial strategy, cost control, investment and financing decisions involving corporate strategy. This requires the practical teaching of accounting majors of applied undergraduate colleges and universities, and we must focus on improving the overall quality of students and strive to cultivate complex talents.

Through the establishment of a financial sharing service center, the company aims to realize economies of scale in financial accounting, thereby streamlining personnel and effectively controlling costs; repealing large amounts of repetitive business operations in the past, realizing professional division of labor, and achieving efficient processing with standardized business processes; therefore, finance The demand for personnel will be greatly reduced. Under such a realistic background, there has been a tremendous impact and impact on the employment situation of applied undergraduate colleges; the future direction, advantages, and prospects of the finance and accounting profession are worth pondering.

The accounting professional teachers must not only have a solid theoretical foundation, but also have rich practical experience. However, at present most of the teachers in applied-type undergraduate colleges are highly educated and theoretical. They all possess extremely professional theoretical knowledge, but they lack the practical experience to enter the society and enter the enterprise; they have theoretical knowledge and practical ability in finance and accounting. There is a certain degree of difference. If there is a lack of practical experience, teaching can only be 
confined to teaching and learning according to the present; especially in the Internet + , big data, and financial sharing to promote the development of today, teaching that is far from practice will certainly hinder the practice of applied-type colleges The rapid development of teaching.

\section{The Design and Application of Financial Sharing Simulation Training Platform in Practical Teaching}

The financial sharing simulation training platform utilizes advanced image equipment to simulate different-scale and multi-industry companies in real-life scenarios. It uses business-driven finance to allow financial services to be used for business management to achieve business financial integration. At the same time, financial sharing is simulated. The training platform is based on the "financial sharing service center" to enable students to experience and use the Internet to integrate physical accounting services at different locations into the SSC (shared service center) for accounting and analysis. Students can fully feel the Internet technology, Artificial intelligence participates in the core changes in finance and business, which can comprehensively cultivate students' financial accounting ability and decision analysis ability.

The financial sharing simulation training platform is mainly composed of a number of systems such as a financial sharing enterprise application training teaching platform, a financial sharing center teaching management system, an integrated training system, and an image teaching system.

The technology mainly uses the Kingdee K/3 Cloud system, which is mainly built on the current industry-leading financial cloud computing platform, and uses Kingdee software to accumulate industry data of nearly 20 years as a basis to create a leading Internet financial sharing cloud service platform. Through intelligent intervention, teaching becomes possible anywhere, anytime.

The operation is highly operational. After mastering accounting basics, tax laws, auditing, and other basic theoretical knowledge, professional accounting students can use the financial sharing simulation training platform to deeply identify various accounting positions and roles in the enterprise. Knowing, through the real background of enterprise information, students can realize the actual control of the group's financial accounting, and greatly improve the students' practical skills.

The application integrates a variety of experimental models, not only to meet the practical teaching of accounting students, but also in-depth study of financial management disciplines to achieve the quality and skills of accounting personnel training, so as to achieve social orientation, to achieve social and economic benefits.

The financial sharing simulation training platform mainly designs three practical teaching modes:

First, the financial sharing service center operation management teaching model. Taking the case of the Financial Shared Service Center as a teaching background, students are allowed to act as multiple posts in the financial sharing service center to realize business collaboration and processing. At the same time, the operational efficiency and quality in the financial sharing center are continuously optimized and analyzed.

Second, based on the financial management model of the financial sharing service center. Combining business finance, strategic finance, and shared finance, with financial sharing as the core, it fosters the ability of the student group to manage and control financial affairs, and assists companies in achieving financial transformation from a cost center to a profit center.

Third, the financial sharing center consults and plans the model. Taking the typical group management and control of corporate financial management transformation cases as background, students can start from the case study, conduct research and analysis, and design a mode of transformation from traditional group financial control to financial sharing, and participate in planning, implementation, and going online to help enterprises. Realize the collaborative optimization design of business and financial processes.

The practical teaching content of the financial sharing simulation training platform mainly includes: the financial sharing service platform management model, cost sharing, coping and sharing, cashier sharing, asset sharing, accounting sharing and report sharing, covering a wide range, can fully understand the tasks Processing quality and timeliness. 
Based on the existing practical teaching courses, the financial sharing simulation training platform can achieve comprehensive resource and information sharing.

Based on the existing practical teaching construction, the financial sharing simulation training platform can construct a comprehensive training platform including enterprise management, simulation of financial accounting, enterprise practice center, and actual operation simulation of enterprises. It does not waste the resources of the original practical teaching courses, but also connects the various systems to each other, achieves functional interaction, and shares information and resources.

Specifically, it can complete the scene-type comprehensive simulation experiment of financial management and accounting, the financial accounting simulation, the electronic tax reporting simulation experiment, the audit training, the cashier practical training, the financial management financial analysis practice training, these parts include The content of the original practice teaching is also enhanced through financial sharing services. At the same time, the financial sharing simulation training platform can also be upgraded based on the existing laboratory or training platform of the school to form a stepwise increase in the practice of financial accounting teaching. And comprehensive development.

The use of financial sharing simulation training platform can strengthen the cultivation of compound talents, and promote the transition of financial personnel to management and strategy.

Under the trend of the development of financial sharing, the importance of financial accounting has gradually weakened, and the role of management accounting has become increasingly prominent. The demand for financial personnel of enterprises is no longer limited to accountable and accountable accounting talents. More needs are Compounding talents with expertise in finance and accounting; that is, not only mastering accounting theory and practice operations, but also proficient in capital operation, tax planning, management accounting and other aspects of knowledge; at the same time also mastering certain computer technologies, having analysis problems and solving problems. ability.

In China, ZTE Corporation and Haier Group, the first to achieve financial sharing, have divided financial personnel into three types: business finance, strategic finance, and shared finance. Therefore, in the long run, the demand for accounting finance is gradually decreasing, and the demand for compound talents is increasing.

Therefore, the cultivation mode of talents for accounting in applied-type colleges and universities needs to focus on financial accounting, pay attention to the cultivation of accounting ability, and focus on management accounting. Attention should be paid to cultivating students in accounting, auditing, financial management, capital operation, taxation, etc. Comprehensive talents with comprehensive knowledge in many fields such as finance, computer and enterprise management. To promote the transformation of the role of financial personnel, on the basis of focusing on traditional financial accounting, more emphasis on the transition to management and strategic talent.

The use of the financial sharing simulation training platform can strengthen school-enterprise cooperation, innovate the integration of production, study and research, and provide students with opportunities for internship and entrepreneurship.

With the use of the financial sharing model in China, enterprises prefer to use third parties as the operating agency for the financial sharing service center. On the one hand, they can reduce the labor costs of the company. On the other hand, they can also allow some management risks to be effectively controlled. The transition of the finance department from the cost center to the profit center, therefore, the future companies will use the functions of some financial sharing to expand the business into more fields and industries.

It can be predicted that in the future, the school will assist enterprises to undertake some social service functions, such as undertaking some businesses of the company's financial sharing center, financial management training services, and corporate financial sharing management consulting services. These businesses will provide students with more employment channels, and even start projects and opportunities. With the continuous deepening of financial sharing teaching and social 
services, the school will have a large number of corporate business data precipitation, better integration of production, learning and research, the formation of teaching, scientific research big data, thus giving instruction in teaching, employment and entrepreneurship Our students have more support and cultivated "accounting professionals who understand business".

The use of the financial sharing simulation training platform can strengthen the construction of the teaching staff, supplement the dual-qualified personnel, and comprehensively improve the teaching quality.

The establishment of a financial sharing simulation training platform can, to a large extent, increase the practice opportunities for professional accounting teachers to directly participate in this new type of financial management model in the era of big data, truly approach the business, experience and learn, and continuously improve professional practice. ability.

On the other hand, through the establishment of a financial sharing simulation training platform, we can increase the cooperation in teaching and scientific research, increase opportunities for professional teacher training and exchanges, and walk into the group companies that implement the financial sharing model to observe and learn; we can also hire experienced people. Dual-education managers will come to the school for learning exchanges and share rich practical experiences in the form of lectures and academic reports. In the design of practical teaching sessions and curriculum setting, it is possible to increase exchanges with dual-qualified management personnel of enterprises to discuss It enhances the practicality, pertinence and effectiveness of teaching, and at the same time improves the quality of teaching, and really allows students to apply what they have learned.

\section{Conclusion}

Practice teaching is the core of talent training in accounting for applied universities. The content of practical teaching must meet the needs of society and enterprises. The establishment of a financial sharing simulation training platform is the actual implantation of financial sharing services into practical teaching. Among the links, the model of financial sharing services is an important part of practical teaching. Reforming the traditional teaching model, changing the teaching concept, positioning talent training with professional demand orientation, innovating the teaching environment, intensifying practical teaching, enhancing the teaching ability of the teaching staff, promoting the integration of production, study and research, and cultivating the overall quality of students to achieve the full development of students.

\section{References}

[1] Ni Min. Research on practice teaching reform of financial management based on financial sharing service model[J]. Journal of Jilin Institute of Engineering and Technology Teachers, 2017(2):47-49

[2] Ren Qizhe, Huang Zhen. Reflections on the improvement of accounting professional practice teaching under the environment of financial sharing[J]. International Business Finance and Accounting, 2017(7):60-63

[3] Yan Xia. Research on the Transformation of Accounting Professional Training Mode in Colleges and Universities under the Trend of Financial Sharing[J]. Educational Accounting Research, 2015(8):85-88

[4] Zeng Huifen. Thinking on Talent Training Model of Finance and Accounting under the Trend of Financial Sharing Service in the "Internet+" Era[J]. Journal of Heihe University, 2018(1): 101-102

[5] Wang Zhe. Research on the accounting talent training model of colleges and universities based on financial sharing[J]. Chinese Journal of Management Information, 2017(10):40-42 